emerald
PUBLISHING

Tourism Review

\title{
Understandings of Tourism Theory
}

\begin{tabular}{|r|l|}
\hline Journal: & Tourism Review \\
\hline Manuscript ID & TR-07-2017-0120.R1 \\
\hline Manuscript Type: & Research Paper \\
\hline Keywords: & Theory, Theoretical perspectives, Tourism research, Tourism management \\
\hline & \\
\hline
\end{tabular}

SCHOLARONE ${ }^{m}$

Manuscripts 


\section{Understandings of Tourism Theory}

Purpose: This paper explores perceptions of tourism theory and its usefulness to the professional practice of tourism management as identified by the two major stakeholder groups - academics and tourism practitioners.

Design/methodology/approach: Data for this study were collected through the use of two electronically administered surveys with tourism academics teaching on undergraduate tourism programmes of study and tourism professionals, both based in the UK.

Findings: Findings suggest that tourism theory is important in understanding tourism itself. But at the same time it has pragmatic relevance, facilitating researchers and others to make sense of the real world and contributing to successful practice in tourism.

Originality/value: This is the first study to provide empirical data from both academic and practitioner perspectives into often contested debates about the nature and uses of tourism theory.

Keywords: Theory; Theoretical perspectives; Tourism research; Tourism management 


\section{Introduction}

As a relatively young field of study, tourism has received criticisms by scholars over its legitimacy and disciplinary status. In these terms, tourism is criticized for lacking concise definition, or its own unique theories, and being a by-product of other disciplines (Taillon and Jamal, 2009). Moreover, the field is criticized for focusing too heavily on theoretical academic research and lacking practical application in the world of business (Jenkins, 1999).

Other scholars have different perspectives. Franklin and Crang (2001) characterized tourism research as prioritizing industry-led tourism management perspectives at the expense of theoretical knowledge. Abram (2010) argued that theoretical academic research need not necessarily be defined as the opposite of practical knowledge. More recently, McKercher and Prideaux (2014) argued that "rather than writing that tourism lacks theory, one could even more meaningfully argue that tourism has too many different "theories"' (p. 24).

These contradictory statements cast an aura of uncertainty on the state of tourism theory and its relevance to industry practice. This paper explores the contested topic of the meaning and uses of tourism theory. Against a background that sets out some of the many contrasting and often conflicting views about tourism theory it offers empirically based findings from the two major stakeholder groups - academics and tourism practitioners. In doing so it throws light on what these two groups recognise as the nature and use of tourism theory. The emphasis is particularly on the UK experience and on literature created mostly by writers that have English as their primary language. This is not meant to diminish in any way the importance of nonEnglish studies. Instead, the purpose here has been to structure the research around the main themes of the existing controversies over what is seen as theory in tourism, which are more prominent in the English tourism literature (Mura et al., 2017).

\section{About Tourism Theory}

Despite the lack of agreement about what constitutes theory in the social sciences, a common academic connotation of the term is that what is presented as theory implies 
intellectual sophistication and is in this sense superior to the atheoretical (Smith and Lee, 2010). As a result, many tourism journal editors expect submissions to be positioned in a theoretical context and demonstrate their contribution to theory (e.g. Franklin and Crang, 2001; Perdue et al., 2009; Xiao et al., 2013).

The question that typically arises at this point is "What is theory?" Corvellec's (2013) work is particularly apposite at this juncture - as an illustration of the multi-faceted nature of theory in the social sciences - since he specifically addresses this very question in his book What is Theory? Answers from the Social and Cultural Sciences. In this edited volume, which spans contributions from a range of disciplines - history, sociology, ethnology, philosophy, economics, organisation theory, among others and which is, perhaps unsurprisingly, full of diverse and sometimes contradicting propositions, one observation that is made time and time again is that theory is an illdefined notion, meaning different things to different disciplines and discourses; that the complex and elusive nature of theory rules out a clear-cut formulation of what theory is. Thus, in Corvellec's words, "What is theory?" is a challenging question that "can elicit a wide range of answers, depending on how you ask, whom you ask, when you ask, where you ask the question, and for what purpose" (p. 10).

An appeal to Webster Online Dictionary (WOD, 2014) lends support to Corvellec's argument. According to WOD, a "theory" generally denotes a doctrine, which terminates in speculation or contemplation, without a view to practice. This seems to correspond with the practitioners' use of the word theory, as "theoretically" or "intheory". The second definition provided by WOD is theory as the general or abstract principles on which a body of knowledge is founded. This is of interest to those thinkers who see theory as reflecting an intellectual perspective on some phenomenon under study. Mention of general principles also hints at the issue of generalizability, which links theory to the empirical sciences.

This is getting very puzzling and an appeal to the academic literature does little to clarify this confusion. By way of illustration, Eisenhardt (1989) posited that a theory is a fully explained set of conceptual relationships that can be tested empirically. But for Wacker (1998, p. 364) the definition of theory extends beyond "theory as 
explanation" to answer also "the natural language questions of who, what, when, where, how, should, could and would". Weick (1995) adopts a positivistic view that theory needs to predict events and objects, not just explain a few results. Other researchers cite a list of elements that do not constitute theory that include: concepts, references, categories, descriptions, metaphors, data, diagrams, models, hypotheses, frameworks, and typologies (Bacharach, 1989; Sutton and Staw, 1995). On the contrary, Weick (1995) considers theory to belong in the family of words that includes hypothesis, model, typology, and conception.

Within tourism literature, this lack of consensus on the meaning of theory is nothing new. This is perhaps unsurprising given the wide influences on theory in tourism that embrace social theory and wider social science theory and beyond. Searching appropriate databases with the terms "theory" and "tourism" yields a wealth of studies illustrating the enormous breadth of the existing literature. Approaching tourism theory in this way, however, would be a daunting task. Instead, in the ensuing analysis we present a range of studies that are useful to discussions of theory in tourism - i.e. exhaustiveness lies beyond the scope of this article. Taken together, these studies provide a broad set of insights illustrative of the diversity of controversies and answers over what is seen as theory in tourism. To borrow from Corvellec (2013, p. 13) again, "one does not need be exhaustive to represent such diversity", and while diversity is part of the discussions offered here, exhaustiveness is not.

Smith and Lee (2010) tackled this diversity directly through content analysis of research articles appearing in three top-tier tourism journals to examine the ways "theory" has been used in tourism research. On this basis they developed a typology of "theory" in tourism, which identified seven distinct applications of the word theory by tourism scholars: "traditional" theory of the type used in the natural sciences; theory synonymous with an a priori, usually empirical, model that generates falsifiable predictions; theory equated with statistical models that are formulated and presented as theory without conceptual guidance from a priori models; theory as an unfalsifiable verbal or graphic model; epistemology presented as theory; grounded theory; and the use of the term in a casual sense or the application of an existing theory as an analogy in tourism. In relation to this classification they suggested that 
while there has been a growing tendency of (tourism-related) researchers to attend to theoretical claims and explanations over the last twenty years, the term "theory" is increasingly being used so broadly that it is in danger of becoming meaningless.

Indeed, inconsistencies in the meaning of "theory" can be found in the views of several mainstream tourism scholars. Working from an educational perspective, Ritchie et al. (2008) argued that tourism curricula should be grounded within theories appearing in research literature. In presenting their argument, the authors began with a discussion of the nature of theory in the natural sciences, implying that tourism theory should also be based on substantial empirical evidence and falsifiable hypotheses, having explanatory and predictive power. Dann et al. $(1988$, p. 4) share a similar view, suggesting: "A theory that does not predict is one which fails to identify the strength and direction of relationships within a framework of probability propositions". Similarly, for Smith and Lee (2010) a theory that lacks empirical grounding and does not produce falsifiable predictions amounts to nothing more than speculation.

In contrast, the work of Pearce (1982) and Xin et al. (2013) clearly denotes that tourism theory can also emerge through conceptual inquiry. They propose that conceptual research allows for multiple mental constructions depending mainly on the persons that create them for their form. This suggests that different scholars may construct theories in different ways according to the worldview assumptions that they bring to their inquiry. This implies a view of theory as a subjective lens through which investigated phenomena may be understood, rather than empirical testing that provides falsifiable predictions.

Another controversial issue in tourism studies is the extent to which the field ought to develop a holistic theoretical underpinning. One early attempt to address this topic was Leiper's (1981) paper, which sought to make a case for a distinct discipline in tourism. He argues that the disciplinary barriers impacting on tourism have fragmented tourism studies and that an integrated theory of tourism would bypass this fragmentation. Taking a similar view, Rogozinski (1985) argues that the singling out of such disciplines as the economy, geography, and sociology of tourism corresponds 
to the tendency towards specialization, which impedes reaching consensus on a distinctive tourism theory. Similar calls for a holistic approach to the theory of tourism are also evident in writings from Jovicic (1988), Meethan (2001), and Noy (2007). At the heart of these calls is the assumption that the extent to which a distinct body of theory has been established represents a sign of maturity of tourism studies.

Other tourism scholars, nonetheless, have been unwilling to endorse the potential of tourism studies to develop a single theory. Among them Aramberri (2010) and McKercher and Prideaux (2014) indicate that there is no point looking for a general theory of tourism and that diverse theoretical perspectives should be applied in its study. Franklin and Crang (2001, p. 6) make this point clearly: "The theoretical net needs to be cast much wider so that tourist studies is constantly renewed by... theory from other disciplines". From this view, multidisciplinary research implies a maturation of tourism as a field of study in that diverse disciplines are being used to promote understanding in tourism (Tribe and Airey, 2007). In this spirit of disciplinary pluralism, Ritchie et al. (2008) suggest that the interactions between tourism and traditional disciplines are based on two-way exchanges of information and knowledge, for mutual benefit. This implies that tourism should not just be an importer of ideas from other disciplines, but also an exporter to other branches of science.

While the extent to which theory enhances understanding in a field of study is clearly a key element by which to judge theoretical progress, other factors also need to be considered. This is particularly the case for eclectic fields of study such as tourism, which also incorporate a "management stream", that, as the name suggests, concerns the needs of the professional business environment (Ritchie et al., 2008, p. 2). This implies that in tourism studies it is generally viewed as important for scholars not only to advance understanding of tourism, but also to address the issue of practical utility i.e. the contribution of theory to current managerial practice (Xin et al., 2013).

Practical utility is a long-standing theme in tourism writings. In this respect, there are concerns about the insular world of tourism academics, who have established their own communication outlets independent from professional audiences (Aramberri, 
2001), and the extent to which tourism theorizing emerges as a displacement activity from management practices (Abram, 2010). There is also questioning about academics' inattention to the practical applicability of their research, which has led to a troubling disconnect between tourism academia and industry (Jenkins, 1999; Harrison, 2010). For Getz (2007), this lack of gearing between the academic community and the tourism industry is an indication of the field's relative immaturity. He observes that "At some point of maturity, it becomes accepted wisdom that professional managers MUST understand some of the underlying theory [and] be able to discuss important meaning" (p. 5).

Abram (2010) offers a more optimistic view, arguing that findings and theory from tourism research certainly emerge into practitioner consciousness and that the problem is that "we cannot necessarily predict in which direction our theorizing might go nor when theoretical speculation may spark the interest of practitioners". At the same time she argues that theoretical academic research and practical knowledge are not necessarily mutually exclusive. Such a view is also echoed by Xiao and Smith (2007, p. 322), who suggest that "theory development and research designs in tourism can be guided by applications of concepts such as... usability and usefulness".

To summarize, part of the difficulty in delineating the elusive nature of tourism theory is that tourism studies is an eclectic field. Not only do tourism scholars borrow from many other disciplines for ideas and insights for theory building, but they often have to speak to both academics and practitioners. This medley of foundations and audiences often creates confusion about the nature and uses of tourism theory. It is in view of such confusion that this study probes into academic and practitioner understandings of tourism theory.

\section{Methodology}

Data for this study were collected through the use of two questionnaire surveys with tourism academics teaching on undergraduate tourism programmes of study and tourism professionals, both based in the UK. With respect to the population of academics, a list of eligible institutions was obtained by using UCAS (2015) statistics. This gave the finding that there were 122 institutions offering tourism undergraduate 
level courses in the UK during academic year 2014/2015. A search of their websites resulted in the identification of a total of 640 respondents and their e-mail addresses.

For the professionals a total of 712 respondents and their e-mail addresses were identified from the 2014 Membership Directory of the Tourism Society. The Society is a UK based membership organisation for professionals in tourism (http://www.tourismsociety.org/). Most of the members are based in the UK and it includes academics among its members. For the purposes of this survey members based outside the UK and academic members were excluded.

Each sample group completed a different questionnaire (available from the authors). All questions were similar, but questions about the respondents' backgrounds were different for the two groups. The questionnaire of the academics asked questions about their demographic characteristics, disciplinary background, current employment and the type of department they worked in. For the professionals the focus was on demographic information, current employment and characteristics about their organisation. Professionals were also asked to indicate whether they had taken a course of training or education in tourism and whether they had a tourism-related qualification. Notwithstanding the fact that neither the disciplinary background of academics nor whether the professionals had had tourism education/training had any significant influence on their responses the omission of disciplinary background in relation to the professionals is nevertheless raised as a limitation in the final section of this article.

Both survey instruments had four sections. The first section of the questionnaire included questions related to demographic and background characteristics of respondents. The second section inquired about the respondents' understanding of the word "theory". For the purpose of this case seven definitions of "theory" representing the typology of theory in tourism developed by Smith and Lee (2010) were used and respondents were asked to select the one that comes closest to their understanding of the term. These definitions were taken from published sources or developed by the authors (see Table 3). The third section included items that measured respondents' views about the importance, nature and use of theory in relation to tourism, the fourth 
section included items that measured their views about the usefulness of tourism theory. Items in sections three and four were measured on a five-point Likert scale ranging from $1=$ strongly disagree to $5=$ strongly agree.

The questionnaires were administered electronically through a web-based survey system. An explanation to the study and an embedded link to the survey were sent via an introductory email from the electronic survey host. Participant anonymity was assured by disabling the storage of e-mail and collection of IP (Internet Protocol) addresses. Both surveys were open between May and June 2015, with two reminders to complete, and received a total of 306 responses. Breaking the sample down according to respondents' characteristics did not reveal any useful findings, so the analysis that follows is based on aggregate results - i.e. findings relevant at a group, professional or academic, level.

\section{Findings}

\section{The Respondents}

A total of 640 respondents were identified through a search of the websites of the 122 institutions offering tourism undergraduate level courses in the UK during academic year $2014 / 2015$. A total of 231 of these potential respondents visited the link to the electronic survey and 174 completed the questionnaire. A summary of the descriptive statistics of the respondents is provided in Table 1.

[Table 1 about here]

Most were employed on a full time-basis in departments of tourism and/or hospitality and there was a fairly even spread of respondents by gender, age and position. The largest single group identified with tourism as their discipline or area of study, including those who identified with Tourism Management, Tourism Marketing and Tourism Planning. The category labelled "Other" represents a broad range of subject areas and disciplines from Marketing at 5\%, Hospitality at 4\% as well as Sociology and Psychology at 2\% and Environmental Studies at $1 \%$. The level of experience ranged from 1 year to 40 years with a mean of 15.5 years. In brief therefore this represents a broad range of the population involved in the academic study of tourism. 
With respect to the sample of the professionals, some 184 of the 712 identified respondents visited the link to the electronic survey and 132 completed the questionnaire. A summary of the descriptive statistics of the professional respondents is given in Table 2.

[Table 2 about here]

In common with the membership of the Tourism Society itself, which draws professionals from all sectors of tourism, the respondents to this survey were very diverse with, not surprisingly given the focus of the Society as a professional body, an emphasis on older, more experienced, more senior and highly educated professionals. Within this diversity, it is worth pointing out that the strong majority of these respondents came from the public sector $(68 \%)$ and more than half of them $(54 \%)$ were employed in micro-organisations (up to nine employees). It is also interesting to note that about $50 \%$ of them had had some form of training or education related to tourism and $45 \%$ had a tourism qualification, of which one third cited Fellowship of the Society as their qualification.

\section{Understandings of Theory}

The academics and professionals were both presented with the same set of different definitions of theory and were asked to select the one that best matched their understanding. Restricting respondents to one notion of theory was decided on the consideration that it shows their priority in a complex field. The results are provided in Table 3.

[Table 3 about here]

The broad patterns of their responses were similar with two of the definitions, both emphasising the nature of theory as being a systematic view or model and its role in explaining and predicting, attracting the highest levels of agreement. Within these the academics clearly favoured the more fully elaborated definition emphasising the "interrelated concepts, definitions and propositions" of theory, while for the professionals the words "models and reality" were preferred. The only other definition 
that attracted responses in double figures was the one that set out theory as a "filter through which a researcher selects and interprets data". The first two of these definitions point to the extent to which both groups of respondents view theory as something that plays a part in helping researchers, or others, to understand, interpret or explain reality in the form of data or other phenomena. To this extent theory is seen as being linked to the so-called real world. The link with data is also picked up in the third of these definitions, with a double figure response, again with a suggestion of its usefulness in dealing with data.

\section{The Importance, Nature and Use of Tourism Theory}

Both groups were also asked for their views about the importance, nature and use of theory in relation to tourism by indicating their level of agreement to various statements on a five-point scale (see Table 4).

Both groups agreed about the importance of theory in researching and teaching tourism with, perhaps not surprisingly, the academics taking a rather more positive view. However, these views also extended beyond academic settings to an agreement that theory is important in understanding tourism itself. Here again the professionals lagged behind the academics but even so they were very positive about this, suggesting that for them, theory is not just confined to the work of the academy but is also significant for their world of practice. This point is emphasised in the highest score given by the professionals that theory that is not closely linked to tourism practice will not advance knowledge of tourism management practice. The academics were rather less supportive of this, pointing to some divergence of views in the academy about the extent to which tourism theory needs some empirical grounding.

[Table 4 about here]

The findings also reveal some marked similarities between the academics and the professionals in their views about the state of tourism theory. They are not strongly of the view that tourism has its own body of theory or that tourism is a mature area of study. Similarly they are in broad agreement in their doubts about whether theories from other areas of study are more sufficient or important for understanding tourism. 
Not only do these findings point to the fact that the academics and professionals are taking a somewhat similar view but taken together they provide a pointer to the need to continue effort to develop theory in tourism if we are to understand the phenomenon more clearly, notwithstanding the danger that both groups identify of the proponents of tourism theory in exaggerating its importance.

\section{The Usefulness of Tourism Theory}

As far as the usefulness of tourism theory is concerned there were also more similarities than differences between the two groups of respondents. The results are given in Table 5. The only major area of difference was in relation to the relative importance of tourism theory versus general management theory with the professionals favouring the latter.

[Table 5 about here]

Apart from this, the general levels and patterns of responses are similar. Neither group took the view strongly that tourism theory was irrelevant or decoupled from practice. An understanding of tourism theory was seen as important for a range of different management responsibilities including commercial success, sustainability, ethical behaviour and long term strategic decision making, with the academics judging this rather more positively for each category. Interestingly, and by way of contrast, neither of the two groups took the view that all tourism management practice is inevitably grounded in tourism theory suggesting agreement between them that tourism managers need more than that offered by the tourism theorists.

At the same time, both groups agreed that the role of theory per se in tourism management practice needs to be better understood and both groups pointed fairly strongly to the need for tourism managers to develop a better understanding of tourism theories. There was also some measure of agreement that tourism managers may experience difficulties in following or using tourism theory, suggesting the need to make theory more accessible to professionals.

\section{Conclusions}


To the authors' best knowledge this is the first study to provide empirical data from both academic and practitioner perspectives into the existing controversy over the nature and usefulness of tourism theory. Tourism research has mostly addressed issues of tourism theory using conceptual approaches (e.g. Aramberri, 2001; Xiao and Smith, 2007) or through analyses of the content of published studies (e.g. Smith and Lee, 2010; Xin et al., 2013). As such, this study provides an original contribution to existing literature by offering new empirical insights.

As indicated by the respondents in this study, tourism theory does not exist independently of reality; rather it has pragmatic relevance, facilitating researchers and others to make sense of and explain the so-called real world in the form of data or other phenomena. This takes it beyond abstract principles on which a body of knowledge is founded as suggested by WOD and supported by many of the commentators referred to earlier, and closer to Dann et al.'s $(1988$, p. 4) view that “A theory that does not predict is one which fails to identify the strength and direction of relationships within a framework of probability propositions". This does not go as far as to emphasise falsifiability as a prerequisite but it does suggest that theory needs to have some bearing on reality or as Smith and Lee (2010) suggest a theory needs some empirical grounding. For the perspective of tourism scholars and practitioners, both of whom are dealing, at least in part, with a real world phenomenon this is not all that surprising although the extent to which their views align may be remarkable and indeed comforting for those who view the need for tourism scholarship to be rooted in the real world.

The empirical findings of the study further propose that tourism theory is important in understanding tourism itself. This idea comes across from both academics and professionals. Results suggest "some shakiness in the foundations of tourism", to use Tribe's (2010, p. 31) terminology, as a domain of study in terms of its immaturity which also manifests itself in the lack of its own theory. But at the same time both respondent groups are doubtful about the extent to which theories from other domains are sufficient or more important than tourism theories for understanding tourism. In this sense, tourism theory does not come a poor second to management theory by professionals, which shows that tourism theory is relevant to them. Not only do these 
findings point to the fact that the academics and professionals are taking a somewhat similar view but taken together they provide a pointer to the need to continue effort to develop theory in tourism if we are to understand the phenomenon more clearly; but managers also need more than tourism theory.

These findings seem to imply that tourism researchers must continue borrowing theories from other domains of study for possible importation and use in explaining tourism phenomena. But these other domains of study can also be used to gain knowledge about theory construction. An accumulating body of such knowledge may allow the field to become more explicit with theory construction, in order to expose errors, speed up the process of comparing theories and direct itself in progressive directions. It may also allow tourism to gain more expertise in theorising and developing theories that merit attention from researchers, both inside and outside tourism academia as suggested by Ritchie et al. (2008), and practising managers. In this context, the challenge for tourism researchers appears to be one of balancing the distinct identity of tourism with cooperation with other disciplines and with industry.

The main messages from this study regarding the usefulness of tourism theory are generally positive. There is clearly awareness among the academics and professionals that while tourism theory is not the only contributor to successful practice in tourism, it is seen as important. If tourism researchers attend to this idea that tourism theory and industry practice can work hand in hand, then they may work toward more expansive theorising, which is infused with significance for practice.

This raises the wider question of how mechanisms connecting academia and professionals could be strengthened. Using industry input and insights in the development of research agendas, partnering with professionals to investigate problem areas of shared interest and expertise, engaging in executive education settings and consulting assignments, and receiving feedback from those organisations participating in a study, may provide possible pathways through which academic knowledge and theory can connect to practice. At the same time, this would also require going some way to make tourism theory more accessible to tourism managers and "give sense" to them about the relevance of theoretical work. In communicating 
their findings to wider audiences, therefore, tourism scholars should avoid abstract ideas and academic jargon and should take responsibility for specifying how to implement the theories they produce in real-life professional environments. This, again, may require substantial contact with the professional community to gain insights into the ways practitioners respond to academic knowledge and how such knowledge is understood in practice. Given that many professionals are generally not likely to read journal articles, practice-accessible outlets for the dissemination of academic knowledge are also needed. These may include, but are not limited to, workshops, practical frameworks, cases, research reports, and practitioner-oriented articles (Mohrman and Lawler, 2011). The challenge for tourism academics, then, becomes one of transforming and disseminating their work into forms that are digestible and accessible by professionals. In this spirit, it is the intention of the researchers to examine the possibility of communicating the results of this study to tourism professionals through an article for the Tourism Society quarterly publication.

In closing, it is important to be mindful of the limitations of this study. The fact that it is based solely on the experience of tourism academics and professionals in the UK means that the findings are specific to the British culture and, therefore, cannot be generalised to other cultures. This also extends to the conceptual framing of the study which is largely confined to the English language literature within tourism and authors based in primarily English speaking countries. In this connection, future studies may give more attention to perceptions and contributions from tourism academics working outside English-speaking circles, extending to other language areas to provide insights into understandings of tourism theory among different tourism academic systems. Another limitation of this study, as noted earlier, is that it did not address the disciplinary backgrounds of the non-academics. Even though the analysis here did not reveal any differences among academics from different disciplines, or among any of the characteristics within groups for that matter, addressing the educational/disciplinary backgrounds in more detail of both academic and professional groups may provide important further empirical insights into the ways and extent to which understandings of tourism theory are founded in a disciplinary context. 
With respect to sampling bias, the research categorized respondents as either academics or professionals. In this way it failed to make allowance for respondents with more than one role, i.e. dual professional and academic posts, so it may have somewhat misstated the subgroup allocation. Additionally, the sample of professionals was limited to members of the Tourism Society. It is possible that this group of respondents is not representative of the industry more generally, even in the UK - the large, and perhaps disproportionate, number of professionals employed in the public sector points to this possibility. Future research using wider samples drawn from different national, occupational and organisational contexts is therefore recommended. Checking for non-response bias was also not possible because of limited access to the respondents. Finally, the study limited respondents to choosing one notion of theory. Future studies may seek to elucidate multiple framings and capture rankings of importance of the notions of theory using qualitative analyses.

These limitations apart, the study sheds through its implications some much-needed light to the discussion of the nature and uses of tourism theory - a topic of growing concern and interest for tourism researchers (Smith et al., 2013). The findings reported here have no claims to generalisability. It is hoped however that they will stimulate interest in future studies to further examine issues of tourism theory and its usefulness to tourism management. It is also hoped that they may act as a "call to action" for tourism academia and industry to create and pursue a shared agenda of practically useful tourism research.

\section{References}

Abram, S. (2010), “Anthropology, tourism and intervention?”, in Scott, J. and Selwyn, T. (Eds.), Thinking Through Tourism, Berg, Oxford, pp. 231-254.

Aramberri, J. (2010), "The real scissors crisis in tourism research", in Pearce, D.G. and Butler, R. (Eds.), Tourism Research: A 20-20 Vision, Goodfellow Publishing, Oxford, pp. 15-27.

Ary, D., Jacobs, L.C. and Sorensen, C. (2009), Introduction to Research in Education, Wadsworth Belmont, CA. 
Bacharach, S.B. (1995), "Organizational theories: Some criteria for evaluation", Academy of Management Review, Vol. 14 No. 4, pp. 496-515.

Corvellec, H. (Ed.) (2013), What is Theory? Answers from the Social and Cultural Studies, Copenhagen Business School Press, Copenhagen.

Dann, G., Nash, D. and Pearce, P. (1988), "Methodology in tourism research”, Annals of Tourism Research, Vol. 15 No. 1, pp. 1-28.

Eisenhardt, K.M. (1989), "Building theories from case study research”, Academy of Management Review, Vol. 14 No. 4, pp. 532-550.

Franklin, A. and Crang, M. (2001), “The trouble with tourism and travel theory?”, Tourist Studies, Vol. 1 No. 1, pp. 5-22.

Getz, D. (2007), Event Studies: Theory, Research and Policy for Planned Events, Butterworth-Heinemann, Oxford.

Harrison, D. (2010), “Tourism and development: Looking back and looking ahead more of the same?", in Pearce, D.G. and Butler, R. (Eds.), Tourism Research: A 20-20 Vision, Goodfellow Publishing, Oxford, pp. 40-52.

Jenkins, C. (1999), "Tourism academics and tourism practitioners: Bridging the great divide", in Pearce, D.G. and Butler, R. (Eds.), Contemporary Issues in Tourism Development $\left(2^{\text {nd }}\right.$ ed.), Routledge, London, pp. 499-521.

Jovicic, Z. (1988), “A plea for tourismological theory and methodology", Tourism Review, Vol. 43 No. 3, pp. 2-5.

Leiper, N. (1981), "Towards a cohesive curriculum in tourism: The case for a distinct discipline", Annals of Tourism Research, Vol. 8 No. 1, pp. 69-84. 
McKercher, B. and Prideaux, B. (2014), “Academic myths of tourism”, Annals of Tourism Research, Vol. 46, pp. 16-28.

Meethan, K. (2001), Tourism in Global Society, Palgrave, Basingstoke.

Mohrman, S.A. and Lawler, E.E., III. (2011), "Research for theory and practice: Framing the challenge", in Mohrman, S.A. and Lawler, E.E., III. (Eds.), Useful Research: Advancing Theory and Practice, Berrett-Koehler, San Francisco, pp. 9-35.

Mura, P., Mognard, E. and Sharif, S.P. (2017), "Tourism research in non-Englishspeaking academic systems", Tourism Recreation Research, doi: $10.1080 / 02508281.2017 .128347$

Noy, C. (2007), A Narrative Community: The Voices of Israeli Backpackers, Wayne State University Press Detroit, MI.

Pearce, P. (1982), The Social Psychology of Tourist Behavior, Oxford, Pergamon.

Perdue, R., Meng, F. and Courtney, J. (2009), "Publishing in the Journal of Travel Research: An assessment of manuscript acceptance and rejection" Journal of Travel Research, Vol. 47 No. 3, pp. 267-274.

Ritchie, R.B., Sheehan, L.R. and Timur, S. (2008), “Tourism sciences or tourism studies? Implications for the design and content of tourism programming", Téoros, Vol. 27 No. 1, pp. 33-41.

Rogozinski, K. (1985), "Tourism as a subject of research and integration of sciences", Problemy Turystyki, Vol. 4, pp. 7-19.

Smith, S. and Lee, H. (2010), “A typology of 'theory' in tourism”, in Pearce, D.G. and Butler, R. (Eds.), Tourism Research: A 20-20 Vision, Goodfellow Publishing, Oxford, pp. 28-39. 
Smith, S., Xiao, H., Nunkoo, R. and Tukamushaba, E.K. (2013), "Theory in hospitality, tourism, and leisure studies", Journal of Hospitality Marketing \& Management, Vol. 22, pp. 875-894.

Sutton, R. and Staw, B. (1995), "What theory is not", Administrative Science Quarterly, Vol. 40, pp. 371-384.

Taillon, J. and Jamal, T. (2009), "Understanding tourism as an academic community, study, and/or discipline", in Papineu, D. (Ed.), Philosophy, Oxford University Press, Oxford, 4-20.

Tribe, J. (2010), "Tribes, territories and networks in the tourism academy", Annals of Tourism Research, Vol. 37 No. 1, pp. 7-33.

Tribe, J. and Airey, D. (2007), “A review of tourism research”, in Tribe, J. and Airey, D. (Eds.), Developments in Tourism Research, Routledge, London, pp. 3-14.

Universities and Colleges Admissions (2015), "Institution/Subject Group/Domicile Dataset 2014", available at: http://www.ucas.com (accessed 15 March 2015).

Wacker, J. (1998), “A definition of theory: Research guidelines for different theorybuilding research methods in operations management", Journal of Operations Management, Vol. 16, pp. 361-385.

Webster Online Dictionary (2014), “Webster's Dictionary”, available at: http://webster-dictionary.org/ (accessed 3 March 2016).

Weick, K.E. (1995), "What theory is not theorizing is", Administrative Science Quarterly, Vol. 40, pp. 385-390.

Xiao, H. and Smith, S. (2007), "The use of tourism knowledge: Research propositions", Annals of Tourism Research, Vol. 34 No. 2, pp. 310-331. 
Xiao, H., Jafari, J., Cloke, P. and Tribe, J. (2013), “Annals: 40-40 vision”, Annals of Tourism Research, Vol. 40, pp. 352-384.

Xin, S., Tribe, J. and Chambers, D. (2013), “Conceptual research in tourism”, Annals of Tourism Research, Vol. 41 No. 1, pp. 66-88. 
2

3

4

5

6

7

8

9

10

11

12

13

14

15

16

17

18

19

20

21

22

23

24

25

26

27

28

29

30

31

32

33

34

35

36

37

38

39

40

41

42

43

44

45

46

47

48

49

50

51

52

53

54

55

56

57

58

59

60

Table 1: Profile of Academic Respondents

\begin{tabular}{|l|l|l|l|l|l|}
\hline $\begin{array}{l}\text { Type of Department/ } \\
\text { Structure }\end{array}$ & $\begin{array}{l}\text { Tourism/ } \\
\text { Hospitality }\end{array}$ & $\begin{array}{l}\text { Business } \\
\text { Studies }\end{array}$ & Other & & \\
\hline$\%$ & 67 & 30 & 3 & & \\
\hline Gender & Male & Female & & & \\
\hline$\%$ & 51 & 49 & & & \\
\hline Age & Under 30 & $\mathbf{3 0 - 3 9}$ & $\mathbf{4 0 - 4 9}$ & $\mathbf{5 0 - 5 9}$ & $\begin{array}{l}\text { Over } \\
\mathbf{6 0}\end{array}$ \\
\hline$\%$ & 3 & 24 & 32 & 25 & 16 \\
\hline Position & Lecturer & $\begin{array}{l}\text { Promoted } \\
\text { Lecturer }\end{array}$ & Professor & Other & \\
\hline$\%$ & 21 & 55 & 14 & 9 & \\
\hline Employment & Full-time & Part-time & & & \\
\hline$\%$ & 85 & 15 & & & \\
\hline Subject Area & $\begin{array}{l}\text { Tourism \& } \\
\text { related }\end{array}$ & Geography & Events & $\begin{array}{l}\text { Culture/ } \\
\text { Heritage }\end{array}$ & Other \\
\hline$\%$ & 43 & 13 & 8 & 7 & 29 \\
\hline
\end{tabular}


Table 2: Profile of the Professional Respondents

\begin{tabular}{|c|c|c|c|c|c|}
\hline Gender & Male & Female & & & \\
\hline$\%$ & 68 & 32 & & & \\
\hline Age & Under 30 & 30-39 & $40-49$ & $50-59$ & Over 60 \\
\hline$\%$ & 1 & 5 & 15 & 34 & 44 \\
\hline Education & Secondary & Graduate & Postgrad & & \\
\hline$\%$ & 11 & 34 & 55 & & \\
\hline Position & MD/CEO & $\begin{array}{l}\text { Divisional/ } \\
\text { Area } \\
\text { Manager }\end{array}$ & $\begin{array}{l}\text { Dept. } \\
\text { Manager }\end{array}$ & $\begin{array}{l}\text { Team/ } \\
\text { Project } \\
\text { Leader }\end{array}$ & Other* \\
\hline$\%$ & 39 & 11 & 16 & 8 & 26 \\
\hline Employment ** & Full-time & Part-time & & & \\
\hline$\%$ & 71 & 29 & & & \\
\hline $\begin{array}{l}\text { Experience } \\
\text { position) } * *\end{array}$ & Up to 5 years & 5-10 years & 11-20 years & $\begin{array}{l}20 \text { years } \\
\text { plus }\end{array}$ & \\
\hline$\%$ & 31 & 15 & 30 & 24 & \\
\hline $\begin{array}{l}\text { Tourism } \\
\text { Education/Training }\end{array}$ & Yes & No & & & \\
\hline$\%$ & 52 & 48 & & & \\
\hline Tourism qualification & 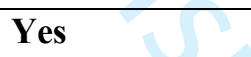 & No & & & \\
\hline$\%$ & 8 & 55 & & & \\
\hline Sector 1** & Public & Private & Voluntary & & \\
\hline$\%$ & 68 & 29 & 3 & & \\
\hline Sector $2 * *$ & $\begin{array}{l}\text { Destination } \\
\text { Management }\end{array}$ & $\begin{array}{l}\text { Accommo } \\
\text { dation }\end{array}$ & Consult & Other*** & \\
\hline$\%$ & 32 & 14 & 14 & 42 & \\
\hline No of Employees** & Less than 10 & $10-49$ & $50-250$ & 250 plus & \\
\hline$\%$ & 54 & 18 & 12 & 16 & \\
\hline Focus ** & International & National & Local & & \\
\hline$\%$ & 24 & 33 & 43 & & \\
\hline
\end{tabular}

*: Includes consultant, retired and chairman; **: Excluding retired; ***: Incudes Transport, Attractions, Travel Trade, Food and Beverage, Trade Associations, Training, Tourist Guiding, Social Tourism. 
2

3

4

5

6

7

8

9

Table 3: Understanding of the Word "Theory"

\begin{tabular}{|l|c|c|c|}
\hline Definitions of Theory & Source & Academics & Professionals \\
\hline $\begin{array}{l}\text { A theory is a set of interrelated concepts, } \\
\text { definitions, and propositions that present a } \\
\text { systematic view of phenomena by specifying } \\
\text { relations among variables, with the purpose } \\
\text { of explaining and predicting the phenomena. }\end{array}$ & $\begin{array}{c}\text { Ary et al. } \\
(2009, \mathrm{p} .15)\end{array}$ & $55 \%(96)$ & $32 \%(42)$ \\
\hline $\begin{array}{l}\text { A theory is a model of reality that helps us to } \\
\text { understand, explain and predict that reality. }\end{array}$ & $\begin{array}{c}\text { Developed by } \\
\text { the authors }\end{array}$ & $26 \%(46)$ & $46 \%(61)$ \\
\hline $\begin{array}{l}\text { A theory refers to statistical models that test } \\
\text { speculative causal relationships among } \\
\text { variables but without an a priori model. }\end{array}$ & $\begin{array}{c}\text { Smith and Lee } \\
(2010, \text { p. 33) }\end{array}$ & $1 \%(1)$ & $1 \%(1)$ \\
\hline $\begin{array}{l}\text { A theory is an untested/untestable verbal or } \\
\text { graphic model. }\end{array}$ & $\begin{array}{c}\text { Smith and Lee } \\
(2010, \text { p. 31) }\end{array}$ & $1 \%(1)$ & $5 \%(7)$ \\
\hline $\begin{array}{l}\text { A theory is a filter through which a } \\
\text { researcher selects and interprets data rather } \\
\text { than suggesting hypotheses that can be } \\
\text { empirically tested. }\end{array}$ & $\begin{array}{c}\text { Smith and Lee } \\
(2010, \text { p. 34) }\end{array}$ & $10 \%(18)$ & $8 \%(10)$ \\
\hline $\begin{array}{l}\text { A theory represents the derivation of } \\
\text { conclusions in the form of themes or } \\
\text { patterns based on a structured, iterative, } \\
\text { subjective coding of a source of data. }\end{array}$ & $\begin{array}{c}\text { Adapted from } \\
\text { Smith and Lee } \\
(2010)\end{array}$ & $5 \%(9)$ & $6 \%(8)$ \\
\hline $\begin{array}{l}\text { A theory represents the extraction of } \\
\text { conclusions from the borrowing of existing } \\
\text { theories from one field to be an analogy in } \\
\text { another field. }\end{array}$ & $\begin{array}{c}\text { Adapted from } \\
\text { Smith et al. } \\
(2013)\end{array}$ & $2 \%(3)$ & $2 \%(3)$ \\
\hline
\end{tabular}


Table 4: About Tourism Theory

\begin{tabular}{|l|c|c|}
\hline Statements & $\begin{array}{c}\text { Academics } \\
\text { (mean) }\end{array}$ & $\begin{array}{c}\text { Professionals } \\
\text { (mean) }\end{array}$ \\
\hline Theory is important in understanding tourism & 4.47 & 3.73 \\
\hline Theory is important in teaching tourism & 4.52 & 3.91 \\
\hline Theory is important in researching tourism & 4.60 & 4.10 \\
\hline Tourism has its own distinct body of theory & 3.31 & 3.22 \\
\hline Tourism is a mature area of study & 3.09 & 2.91 \\
\hline $\begin{array}{l}\text { Theories from other domains of study are sufficient } \\
\text { to understand tourism }\end{array}$ & 2.74 & 3.09 \\
\hline $\begin{array}{l}\text { Theories from other domains of study are more } \\
\text { important than tourism theories in understanding } \\
\text { tourism }\end{array}$ & 2.61 & 3.05 \\
\hline $\begin{array}{l}\text { Proponents of the importance of tourism theory over- } \\
\text { estimate its importance }\end{array}$ & 3.10 & 3.32 \\
\hline $\begin{array}{l}\text { Tourism theory that is not closely linked to tourism } \\
\text { practice will not help to advance knowledge of } \\
\text { tourism management practice }\end{array}$ & 3.19 & \\
\hline
\end{tabular}


2

3

4

5

6

7

8

9

Table 5: Usefulness of Tourism Theory to the Management of Tourism

\begin{tabular}{|c|c|c|}
\hline Statements & $\begin{array}{l}\text { Academics } \\
\text { (mean) }\end{array}$ & $\begin{array}{l}\text { Professionals } \\
\text { (mean) }\end{array}$ \\
\hline $\begin{array}{l}\text { Tourism theory is irrelevant for those working in } \\
\text { tourism management }\end{array}$ & 2.14 & 2.33 \\
\hline $\begin{array}{l}\text { Tourism theory is decoupled from tourism } \\
\text { management practice }\end{array}$ & 2.96 & 3.21 \\
\hline $\begin{array}{l}\text { An understanding of tourism theory is essential for } \\
\text { managers in making a contribution to sustainable } \\
\text { tourism development }\end{array}$ & 3.96 & 3.52 \\
\hline $\begin{array}{l}\text { An understanding of tourism theory is essential for } \\
\text { managers in achieving commercial success in } \\
\text { tourism }\end{array}$ & 3.49 & 3.12 \\
\hline $\begin{array}{l}\text { An understanding of tourism theory is essential for } \\
\text { managers in making a contribution to ethical tourism } \\
\text { development }\end{array}$ & 3.87 & 3.53 \\
\hline $\begin{array}{l}\text { An understanding of tourism theory is essential for } \\
\text { managers taking long-term strategic decisions in } \\
\text { tourism }\end{array}$ & 3.96 & 3.69 \\
\hline $\begin{array}{l}\text { Tourism managers should develop a better } \\
\text { understanding of tourism theories underlying their } \\
\text { practice }\end{array}$ & 4.00 & 3.70 \\
\hline $\begin{array}{l}\text { All tourism management practice is inevitably } \\
\text { grounded in tourism theory }\end{array}$ & 2.56 & 2.73 \\
\hline $\begin{array}{l}\text { General management theory is more important than } \\
\text { tourism theory for tourism managers }\end{array}$ & 2.90 & 3.50 \\
\hline $\begin{array}{l}\text { The role of theory in tourism management practice } \\
\text { needs to be better understood }\end{array}$ & 4.09 & 3.81 \\
\hline $\begin{array}{l}\text { Tourism theory is difficult to follow for managers } \\
\text { with little or no experience in higher education }\end{array}$ & 3.41 & 3.39 \\
\hline $\begin{array}{l}\text { For tourism managers with little or no experience in } \\
\text { higher education it is easier to train them to } \\
\text { implement a set of standard techniques than it is to } \\
\text { introduce them to tourism theory }\end{array}$ & 3.30 & 3.18 \\
\hline
\end{tabular}

